\title{
PELAKSANAAN SUPERVISI KLINIS KEPALA SEKOLAH UNTUK MENINGKATKAN KINERJA GURU DALAM MENGELOLA PEMBELAJARAN PADA SMA NEGERI 2 SAMBAS
}

\section{Oleh \\ Lili Ng Chui Mi ${ }^{1}$}

\begin{abstract}
Abstrak : Pada kenyataan Guru belum maksimal dalam mengelola pembelajaran. Penelitian ini bertujuan untuk mengungkapkan pelaksanaan supervisi klinis Kepala Sekolah untuk meningkatkan kinerja guru dalam mengelola pembelajaran pada SMA Negeri 2 Sambas. Metode penelitian yang digunakan adalah kualitatif. Data dikumpulkan melalui wawancara mendalam, observasi partisipan, dan dokumentasi serta dianalisis melalui reduksi data, penyajian data, dan kesimpulan.
\end{abstract}

Hasil penelitian ditemukan kinerja guru dalam mengelola pembelajaran belum maksimal, b) Tahap-tahap pelaksanaan supervisi klinis meliputi: (1) perencanaan; (2) pelaksanaan; dan (3) evaluasi, c) persepsi guru terhadap pelaksanaan supervisi klinis Kepala Sekolah mendapat tanggapan positif dari semua guru, d) upaya yang dilakukan Kepala Sekolah dalam mengatasi masalah supervisi klinis meliputi: (1) melaksanakan IHT, (2) memberikan pengarahan dan motivasi pada guru, (3) melakukan tukar menukar informasi (4) memberdayakan guru senior dalam membimbing penyusunan RPP, e) hambatan-hambatan dalam melaksanakan supervisi klinis yakni: (1) berasal dari guru dan Kepala Sekolah, dan f) faktor-faktor yang mendukung kompetensi Kepala Sekolah dalam melaksanakan supervisi klinis meliputi; (1) pendidikan dan pelatihan, (2) seminar, diskusi maupun lokakarya tentang supervisi klinis, (3) pertemuanpertemuan rutin dalam MKKS, (4) studi banding ke daerah yang sudah melaksanakan supervisi klinis.

Kata Kunci : Supervisi klinis, Kepala Sekolah, kinerja dan guru

${ }^{1}$ Lili Ng Chui Mi adalah pengawas sekolah Kab. Sambas 


\section{Pendahuluan}

Sekolah merupakan salah satu organisasi pendidikan yang dapat dikatakan sebagai wadah untuk mencapai tujuan pembangunan nasional. Keberhasilan tujuan pendidikan di sekolah tergantung pada sumber daya manusia yang ada di sekolah tersebut yakni: Kepala Sekolah, guru, siswa, pegawai tata usaha, dan tenaga kependidikan lainnya. Selain itu harus didukung oleh sarana dan prasarana yang memadai. Guru merupakan salah satu komponen yang sangat menentukan untuk terselenggaranya proses pendidikan. Hal tersebut sesuai dengan tujuan

pembangunan nasional dalam meningkatkan kualitas sumber daya manusia agar menjadi masyarakat Indonesia yang maju berdasarkan Pancasila. Keberadaan guru merupakan pelaku utama sebagai fasilitator penyelenggaraan proses belajar siswa. Oleh karena itu, kehadiran dan profesionalisme guru sangat berpengaruh dalam mewujudkan tujuan pendidikan nasional.

Selanjutnya, fungsi dan tugas guru sebagai tenaga profesional menyandang persyaratan tertentu sebagaimana tertuang didalam UndangUndang Republik Indonesia Nomor 20 Tahun 2003 tentang Sistem Pendidikan Nasional dalam pasal 39 (1) dan (2) dinyatakan bahwa:

Tenaga kependidikan bertugas melaksanakan administrasi, pengelolaan, pengembangan, pengawasan, dan pelayanan teknis untuk menunjang proses pendidikan pada satuan pendidikan. Pendidik merupakan tenaga profesional yang bertugas merencanakan dan melaksanakan proses pembelajaran, menilai hasil pembelajaran, melakukan pembimbingan dan pelatihan, serta melakukan penelitian dan pengabdian kepada masyarakat, terutama bagi pendidik pada perguruan tinggi.

Guru memiliki peran yang penting, merupakan posisi strategis, dan bertanggungjawab dalam pendidikan nasional. "Tugas guru sebagai profesi meliputi: mendidik, mengajar dan melatih" ( Usman Uzer, 2002:7). Mendidik berarti meneruskan dan mengembangkan nilai-nilai hidup. Sedangkan mengajar berarti meneruskan dan mengembangkan ilmu pengetahuan dan teknologi. Melatih berarti mengembangkan keterampilan- 
keterampilan pada siswa. Untuk dapat melaksanakan tugas dan tanggung jawab di atas, seorang guru dituntut memiliki beberapa kemampuan dan keterampilan.

Guru merupakan faktor yang paling dominan, karena ditangan gurulah keberhasilan pembelajaran dapat dicapai. Kualitas mengajar guru secara langsung maupun tidak langsung dapat mempengaruhi kualitas pembelajaran. Guru harus mampu berperan sebagai desainer (perencana), implementor (pelaksana), dan evaluator (penilai) kegiatan pembelajaran. Peran dan fungsi guru sangat menentukan keberhasilan dalam usaha peningkatan mutu pendidikan . Untuk itu guru sebagai agen pembelajaran dituntut memiliki kinerja yang baik.

Namun kenyataannya berdasarkan hasil wawancara, observasi awal dan dokumen hasil supervisi yang ada, didapatkan informasi kinerja guru dalam (1) menyusun RPP; (2) penggunaan RPP dalam kegiatan pembelajaran; dan (3) evaluasi hanya 50\% yang dapat dilakukan, dengan demikian dapat dikatakan kinerja guru belum maksimal.

Berdasarkan masalah tersebut di atas maka diperlukan supervisi klinis Kepala Sekolah untuk meningkatkan kinerja guru dalam mengelola pembelajaran. Peranan dan fungsi Kepala Sekolah sangat diperlukan dalam meningkatkan kinerja guru. Peranan Kepala Sekolah ialah bentuk perilaku yang diharapkan pada setiap orang untuk menjalankan fungsinya. Peranan yang harus dilaksanakan Kepala Sekolah sebagaimana diatur dalam Kepmendiknas RI Nomor 162/U/2003 tentang Pedoman Penugasan Guru sebagai Kepala Sekolah adalah sebagai EMASLEC yakni: Educator (pendidik), Manager (pengelola), Administrator (pengadministrasian), Supervisor (penyelia), Leader (pemimpin), Enterpreneur (pengusaha), dan Climate Creator (pencipta iklim).

Berdasarkan uraian di atas tugas Kepala Sekolah yang peneliti maksudkan yaitu sebagai supervisor meliputi: tugas merencanakan program supervisi klinis, melaksanakan supervisi klinis terhadap guru dengan menggunakan pendekatan dan teknik supervisi yang tepat serta menindaklanjuti hasil supervisi klinis terhadap guru dalam pengelolaan pembelajaran.

Beberapa alasan yang mendasari pentingnya supervisi klinis yakni: (1) membantu guru untuk senantiasa memperbaiki dan meningkatkan kualitas 
proses pembelajaran; (2) mendiagnosis dan membantu memecahkan masalahmasalah pembelajaran; (3) membantu guru mengembangkan keterampilan dalam meng-gunakan strategi-strategi pembelajaran; dan (4) membantu guru mengembangkan diri secara terus menerus dalam karir dan profesi secara mandiri.

Menurut Piet A. Sahertian (2008:36) "Supervisi klinis adalah bentuk supervisi yang difokuskan pada peningkatan mengajar dengan melalui siklus yang sistematik, dalam perencanaan, pengamatan serta analisis yang intensif dan cermat tentang penampilan mengajar yang nyata". Hal ini dipertegaskan lagi Permendiknas No. 13 Tahun 2007 tentang "standar Kepala Sekolah /madrasah menjelaskan bahwa Kepala Sekolah harus memiliki dimensi kompetensi kepribadian, manajerial, kewirausahaan, supervisi dan sosial".

Dengan adanya supervisi klinis Kepala Sekolah diharapkan memberi dampak terhadap terbentuknya sikap profesional guru. Sikap profesional guru merupakan hal yang amat penting, karena selalu berpengaruh pada perilaku dan aktivitas guru. Aktivitas tersebut ditunjukkan dengan kinerja guru, dalam mengelola pembelajaran.

Kinerja guru berasal dari kata kinerja dan guru. Kinerja dalam seharihari sering diartikan "sesuatu yang dicapai, prestasi yang diperlihatkan, kemampuan kerja. Kinerja dapat dipergunakan untuk menunjukkan kemampuan suatu organisasi atau manajemen yang berkaitan dengan hasil atau prestasi yang dihasilkan" (Sukari, 1999:49). Berikutnya LAN (1997) kinerja atau performansi diartikan "sebagai prestasi kerja, pelaksanaan kerja, pencapaian kerja, hasil kerja atau unjuk kerja" (dalam Mulyasa, 2009:136).

Kinerja guru akan baik jika guru memiliki kompetensi dasar yakni: (1) menguasai landasan kependidikan; (2) menguasai bahan pelajaran; (3) menyusun program pengajaran; (4) kemampuan mengelola program belajar mengajar: (5) kemampuan mengelola kelas; (6) kemampuan mengelola interaksi belajar mengajar; (7) menilai hasil belajar siswa; (8) kemampuan mengenal dan menterjemahkan kurikulum; (9) mengenal fungsi dan program bimbingan dan penyuluhan; (10) memahami prinsip-prinsip dan hasil pengajaran. 


\section{MASALAH}

1. Bagaimanakah keadaan kinerja guru di SMA Negeri 2 Sambas?

2. Bagaimanakah tahap-tahap pelaksanaan supervisi klinis yang dilaksanakan oleh Kepala Sekolah untuk meningkatkan kinerja guru dalam mengelola pembelajaran pada SMA Negeri 2 Sambas?

3. Bagaimanakah persepsi guru tentang pelaksanaan supervisi klinis Kepala Sekolah untuk meningkatkan kinerja guru dalam mengelola pembelajaran pada SMA Negeri 2 Sambas yang menjadi tanggung jawabnya?

4. Apakah upaya yang dilakukan Kepala Sekolah dalam mengatasi masalah supervisi klinis?

5. Apakah hambatan-hambatan yang dialami Kepala Sekolah saat melakukan supervisi klinis?

6. Apakah faktor-faktor yang mendukung kompetensi Kepala Sekolah dalam melaksanakan supervisi klinis?

\section{TUJUAN PENELITIAN}

Penelitian ini bertujuan untuk mengetahui: (1) keadaan kinerja guru di SMAN 2 Sambas; (2) tahap-tahap pelaksanaan supervisi klinis yang dilaksanakan oleh Kepala Sekolah untuk meningkatkan kinerja guru dalam mengelola pembelajaran pada SMAN 2 Sambas; (3) Persepsi guru tentang pelaksanaan supervisi klinis Kepala Sekolah untuk meningkatkan kinerja guru dalam mengelola pembelajaran pada SMAN 2 Sambas yang menjadi tanggung jawabnya; (4) upaya yang dilakukan Kepala Sekolah dalam mengatasi masalah supervisi klinis; (5) Hambatan-hambatan yang dialami Kepala Sekolah saat melakukan supervisi klinis: (6) Faktor-faktor yang mendukung kompetensi Kepala Sekolah dalam melaksanakan supervisi klinis.

\section{MANFAAT PENELITIAN}

Penelitian ini memberikan manfaat kepada pihak-pihak berikut ini: (1) memberikan kontribusi pengembangan khasanah ilmu tentang pelaksanaan supervisi klinis oleh Kepala Sekolah dalam upaya meningkatkan profesionalisme guru dan mutu pendidikan; (2) sebagai bahan kajian untuk mengembangkan penelitian lebih lanjut tentang pelaksanaan supervisi klinis 
Kepala Sekolah dalam upaya meningkatkan kinerja guru; (3) dapat dijadikan alternatif model pembinaan guru sebagai pengajar di tingkat satuan pendidikan.

\section{METODE PENELITIAN}

Penelitian ini menggunakan (1) pendekatan kualitatif, dengan maksud untuk mendeskripsikan pelaksanaan supervisi klinis Kepala Sekolah untuk meningkatkan kinerja guru dalam mengelola pembelajaran pada SMAN 2 Sambas; (2) kehadiran peneliti adalah sebagai instrumen kunci, sekaligus sebagai pengumpul data, jadi dalam penelitian kualitatif instrumennya adalah orang atau human instrument; (3) lokasi penelitian adalah SMAN 2 Sambas; (4) sumber data dalam penelitian ini adalah Kepala Sekolah, wakil Kepala Sekolah bagian Kurikulum, Sarana, Kesiswaan dan Humas; (5) prosedur pengumpulan data dengan (a) wawancara mendalam digunakan peneliti untuk mengungkapkan berbagai hal yang diketahui oleh informan dalam kaitannya dengan pelaksanaan supervisi klinis Kepala Sekolah untuk meningkatkan kinerja guru dalam mengelola pembelajaran, berikutnya Hamidi (2008:56) mengemukakan "wawancara mendalam berarti menggali informasi atau data sebanyak-banyaknya dari responden atau informan"; (b) observasi partisipan, peneliti gunakan untuk membina hubungan baik dengan informan, sehingga peneliti betul-betul menyelami kehidupan objek pengamatan dan bahkan tidak jarang peneliti kemudian mengambil bagian dalam kehidupan budaya mereka. Hal ini senada dikemukakan oleh Burhan Bungin (2010:116) observasi partisipan adalah "pengumpulan data melalui observasi terhadap obyek pengamatan dengan langsung hidup bersama, merasakan serta berada dalam aktivitas kehidupan obyek pengamatan", dan (c) dokumentasi, penggunaan teknik ini berkaitan dengan pelacakan data tentang kejadian atau peristiwa yang sudah berlangsung lama. Dokumen yang diperlukan adalah program supervisi kunjungan kelas, jadwal supervisi kunjungan kelas, instrumen wawancara pra observasi, instrumen supervisi akademik, instrumen wawancara post observasi, dokumen RPP, buku pengendali supervisi kunjungan kelas, buku catatan pembinaan guru; (6) Analisis data yang digunakan adalah yang dikembangkan oleh Miles \& Huberman (1992:20) yakni: (a) reduksi data adalah merangkum, memilih hal-hal yang pokok, memfokuskan pada hal-hal yang penting, dicari tema 
dan polanya; (b) penyajian data dilakukan dalam bentuk uraian singkat, dan tabel; (c) penarikan kesimpulan atau verifikasi adalah salah satu kegiatan membuat kesimpulan berdasarkan reduksi data dan penyajian data penelitian; (7) Pengecekan keabsahan temuan dilaksanakan dengan (a) memperpanjang masa pengamatan, dua kali dalam seminggu. Perpanjangan tersebut dilakukan untuk observasi dan wawancara kembali dengan sumber data yang pernah ditemui maupun yang baru; (b) triangulasi digunakan untuk mengecek kebenaran data, dalam penelitian ini ditempuh ketiga teknik triangulasi yang dikembangkan Sugiyono (2008:125) yakni: (1) triangulasi sumber; (2) triangulasi teknik; dan (3) triangulasi waktu. (c) Member checking adalah proses pengecekan data yang diperoleh peneliti kepada pemberi data; (8) Jadwal penelitian, penelitian dilaksanakan selama 7 bulan mulai bulan Juli 2011 sampai dengan Januari 2012.

\section{PEMBAHASAN HASIL PENELITIAN}

1. Kinerja guru dalam (1) Penyusunan RPP, semua guru SMAN 2 Sambas memiliki RPP. Hal ini relevan dengan Permendiknas No. 41 tahun 2007 tentang Standar Proses yang menegaskan bahwa guru berkewajiban membuat (a) Rencana Pelaksanaan Pembelajaran (RPP); (b) Pelaksanaan proses pembelajaran; dan (c) penilaian hasil pembelajaran; Penggunaan RPP dalam pelaksanaan pembelajaran. Semua guru menggunakan RPP sebagai pedoman mengajar apabila disupervisi oleh Kepala Sekolah. Namun apabila tidak disupervisi oleh Kepala Sekolah, hanya 2 guru yang selalu menggunakan RPP sebagai acuan mengajar dengan alasan agar Kompetensi Dasar yang diinginkan dapat disampaikan. Selanjutnya 9 guru lainnya kadang-kadang menggunakan RPP dengan alasan sudah tahu atau paham dengan langkah-langkah dalam kegiatan pembelajaran, karena dari tahun ketahun materinya sama. Dengan demikian dapat dikatakan bahwa guru SMAN 2 Sambas dalam kegiatan pembelajaran lebih banyak yang kadang-kadang menggunakan RPP bila dibandingkan dengan guru yang menggunakan; dan (3) Evaluasi, semua guru melaksanakan ulangan tengah semester, ulangan akhir semeter dan ulangan harian minimal dilaksanakan dua (2) kali dalam satu semester, maksimalnya empat (4) kali. Penilaian proses tidak semua guru dapat melaksanakan dalam setiap kali kegiatan pembelajaran di dalam 
kelas, dikarenakan kekurangan waktu. Dengan demikian dapat dikatakan Guru SMAN 2 Sambas sebagian besar tidak dapat melaksanakan penilaian proses setiap kali pembelajaran bila dibandingkan dengan guru yang selalu melaksanakannya.

2. Tahap-tahap pelaksanaan supervisi klinis yang dilakukan Kepala Sekolah meliputi 3 langkah yakni: (a) tahap perencanaan meliputi penyusunan (1) panduan wawancara pra observasi; (2) instrumen supervisi akademik; (3) panduan wawancara pasca observasi; (4) penyusunan jadwal supervisi; (5) menyediakan buku pengendali supervisi; dan (6) menyiapkan buku pembinaan; (b) tahap pelaksanaan supervisi klinis yang dilaksanakan oleh Kepala Sekolah meliputi 3 langkah yaitu: (1) pra observasi, dilaksanakan sebelum mengikuti guru ke kelas dengan menggunakan panduan wawancara yang sudah disiapkan. Pada tahap pra observasi, Kepala Sekolah tidak dapat melaksanakan pada semua gurunya dikarenakan waktu yang tidak memungkinkan, karena Kepala Sekolah juga mengajar. (2) pelaksanaan supervisi kunjungan kelas yang dilakukan oleh Kepala Sekolah dengan menggunakan instrument sebagai acuan untuk penilaian, dan (3) post observasi dilaksanakan setelah pembelajaran di kelas selesai dengan menggunakan panduan wawancara yang sudah disiapkan sebelumnya. Pada tahap post observasi, Kepala Sekolah meminta guru menceritakan kembali kegiatan pembelajaran yang terjadi di kelas sesuai dengan panduan wawancara post observasi yang telah disediakan; (c) tahap evaluasi, Kepala Sekolah memberikan penilaian terhadap berbagai aspek supervisi yang dilaksanakan. Penilaian yang diberikan Kepala Sekolah berpedoman pada item-item yang terdapat pada instrument supervisi akademik yang telah dipersiapkan sebelumnya. Apabila dalam penilaian terdapat aspek yang kurang, maka Kepala Sekolah memberikan saran pada guru yang bersangkutan untuk memperbaiki dan melengkapi pada pertemuan berikutnya dan bagi guru yang penilaian pada setiap aspeknya sudah baik disarankan untuk dipertahankan dan ditingkatkan.

3. Persepsi guru tentang pelaksanaan supervisi klinis yang dilaksanakan oleh Kepala Sekolah mendapat tanggapan positif dan merespon dengan baik. Supervisi klinis yang dilaksanakan oleh Kepala Sekolah dapat membantu guru mengetahui dan menyadari kekurangan dan kelebihan kinerjanya. 
4. Upaya yang dilakukan Kepala Sekolah dalam mengatasi masalah supervisi klinis diantaranya adalah (a) mengadakan In House Training (IHT) bagi semua guru, dengan materi penyusunan RPP dan evaluasi, agar dapat mening-katkan pengetahuan, disiplin dan kinerja guru dalam melaksanakan tugasnya; (b) memberikan pengarahan dan motivasi kepada semua guru. Pengarahan yang diberikan berupa kebijakan baru dan perubahan-perubahan kebijakan dalam sistem pendidikan nasional, Selain itu, Kepala Sekolah juga senantiasa memotivasi guru untuk senantiasa aktif mengikuti kegiatan Musyawarah Guru Mata Pelajaran (MGMP) baik yang didanai oleh pemerintah pusat berupa (Block Grand), maupun MGMP mandiri, hal ini dimaksudkan agar guru memiliki pengetahuan dan wawasan yang luas; (c) melakukan tukar menukar informasi dengan semua guru. Untuk memperoleh informasi yang akurat berkaitan dengan kinerja guru, Kepala Sekolah setiap kali melakukan supervisi senantiasa melakukan tukar menukar informasi dengan guru, khususnya yang berhubungan dengan penyusunan RPP, penggunaan RPP dalam kegiatan pembelajaran dan evaluasi (penilaian hasil belajar);

Memberdayakan guru senior dalam membimbing penyusunan RPP

5. Hambatan-hambatan yang dialami Kepala Sekolah dalam melaksanakan supervisi klinis yakni: (a) berasal dari guru, pada saat akan melaksanakan supervisi masih ada guru yang enggan disupervisi, walaupun sudah terjadwal, dengan alasan belum siap, dan minta supervisi ditunda. Kemudiaan seringnya guru dipanggil untuk mengikuti pendidikan dan latihan baik ditingkat propinsi maupun tingkat nasional; dan (b) berasal dari Kepala Sekolah adalah: (1) sering adanya rapat di Dinas Pendidikan yang secara mendadak; (2) adanya pertemuan Musyawarah Kerja Kepala Sekolah (MKKS); (3) penataran atau pelatihan di tingkat propinsi maupun tingkat nasional; dan (4) banyaknya sosialisasi/MOU tentang penambahan ruang belajar maupun pemberian sarana lainnya baik yang diadakan ditingkat propinsi maupun nasional .

6. Faktor-faktor yang mendukung kompetensi Kepala Sekolah dalam melaksanakan supervisi klinis meliputi: (a) Pendidikan dan pelatihan, sangat berpengaruh pada kualitas pelaksanaan supervisi yang akan dilakukan, agar supervisi dapat berjalan dengan baik serta dapat memberikan masukkan dan manfaat bagi guru, maka sangat diperlukan adanya 
pendidikan dan pelatihan yang terprogram dan berkesinambungan; (b) Seminar, diskusi maupun lokakarya tentang supervisi akademis. Pendidikan dan pelatihan secara terprogram, yang sangat diharapkan oleh Kepala Sekolah adalah seminar, diskusi maupun lokakarya tentang supervisi akademik, sebab menurut Kepala Sekolah, sejak diangkat menjadi Kepala Sekolah belum pernah mengikuti seminar, diskusi maupun lokakarya tentang supervisi akademik. Pada hal, kegiatan tersebut sangat mendukung sekali perolehan keterampilan dan pengetahuan tentang supervisi akademik. Kepala Sekolah sangat mengharapkan adanya kegiatan seminar, diskusi maupun lokakarya yang berkaitan dengan supervisi akademik. Dengan demikian, pengetahuan dan keterampilan akan bertambah yang pada akhirnya dapat melaksanakan supervisi akademik secara profesional serta dapat memberikan manfaat yang besar bagi kemajuan dan peningkatan mutu pendidikan. (c) Pertemuanpertemuan rutin dalam MKKS. Selama ini di Kabupaten Sambas pertemuan antara para Kepala Sekolah jarang dilakukan. Pertemuan Kepala Sekolah dilakukan apabila ada bantuan dana block grand, adapun materinya tidak membahas tentang supervisi, yang selalu dibahas adalah materi yang berkaitan dengan kurikulum. Kepala Sekolah mengharapkan kedepan MKKS mengadakan pertemuan rutin dengan sesama Kepala Sekolah dalam hal membicarakan berbagai masalah yang berkaitan dengan kegiatan supervisi akademik; (d) studi banding ke daerah yang sudah melaksanakan supervisi klinis. Studi banding yang dimaksud bukan sekedar untuk jalan-jalan, tetapi lebih diutamakan untuk menimba pengetahuan dari para Kepala Sekolah di daerah yang telah melaksanakan supervisi klinis. Studi banding sangat diharapkan Kepala Sekolah untuk menambah pengalaman dan pengetahuan serta keterampilan di bidang supervisi akademik.

\section{KESIMPULAN}

Dari temuan penelitian dan pembahasan hasil pada bagian terhadulu, maka dapat disimpulkan: (1) Kinerja guru SMA Negeri 2 Sambas dalam hal menyusun RPP adalah semua guru memiliki RPP, ada yang buatan sendiri, mengadopsi hasil dari kegiatan Musyawarah Guru Mata Pelajaran (MGMP) dan mengcopy serta memodifikasi RPP orang (guru) lain sesuai dengan 
kebutuhan guru dalam melaksanakan tugas mengajar; (2) Penggunaan RPP dalam pelaksanaan pembelajaran, sebagian besar guru SMA Negeri 2 Sambas menggunakan RPP sebagai pedoman mengajar apabila disupervisi oleh Kepala Sekolah. Namun apabila tidak disupervisi oleh Kepala Sekolah, sebagian kecil guru menggunakan RPP; (3) Evaluasi, semua guru melaksanakan penilaian hasil pembelajaran yang meliputi: ulanganm tengah semester, ulangan akhir semester dan ulangan harian maksimal empat (4) kali dan minimal dilaksanakan dua (2) kali dalam satu semester, sedangkan penilaian proses tidak semua guru dapat melaksanakan dalam setiap kali kegiatan pembelajaran di kelas, hal ini dikarenakan kekurangan waktu. (2) Tahap-tahap pelaksanaan supervisi klinis oleh Kepala Sekolah meliputi tiga hal yaitu: (a) tahap perencanaan; (b) tahap pelaksanaan; dan (c) tahap evaluasi. (3) Persepsi guru SMA Negeri 2 Sambas terhadap pelaksanaan supervisi klinis Kepala Sekolah ditanggapi secara positif, karena dengan adanya supervisi klinis oleh Kepala Sekolah dapat membantu guru mengetahui dan menyadari kekurangan dan kelebihannya dalam melaksanakan tugas di sekolah; (4) Upaya yang dilakukan Kepala Sekolah dalam mengatasi masalah supervisi klinis yakni: (a) mengadakan In House Training (IHT) bagi semua guru SMA Negeri 2 Sambas dengan maksud untuk meningkatkan pengetahuan, disiplin dan kinerja guru dalam melaksanakan tugasnya; (b) memberikan pengarahan dan motivasi kepada semua guru; (c) melakukan tukar menukar informasi dengan semua guru; (d) memberdayakan guru senior dalam membimbing penyusunan Rencana Pelaksanaan Pembelajaran (RPP); (5) Hambatan-hambatan yang dialami oleh Kepala Sekolah dalam melaksanakan supervisi klinis yakni: (a) berasal dari guru adalah saat akan disupervisi guru minta ditunda; dan (b) dari Kepala Sekolah adalah sering adanya pertemuan mendadak dari kantor Dinas Pendidikan, sehingga supervisi yang direncanakan tidak dapat dilaksanakan. (6) Faktor-faktor yang mendukung kompetensi Kepala Sekolah dalam melaksanakan supervisi klinis yakni: (a) pendidikan dan pelatihan; (b) seminar, diskusi maupun lokakarya tentang kepengawasan secara berkala; (c) pertemuan-pertemuan rutin dalam MKKS; (d) studi banding ke daerah yang sekolahnya sudah melaksanakan supervisi klinis . 


\section{SARAN-SARAN}

1. Kepala Sekolah sebaiknya melaksanakan supervisi klinis secara kontinyu, dengan maksud agar guru dalam kegiatan proses pembelajaran semakin baik dan akhirnya dapat meningkatkan hasil belajar siswa.

2. Agar guru membuat Rencana Pelaksanaan Pembelajaran (RPP) sendiri, karena lebih mudah digunakan dan diterapkan, sekaligus menambah wawasan dalam menyusun RPP.

3. Dalam kegiatan pembelajaran di kelas, agar menggunakan RPP sebagai acuan mengajar, sehingga Kompetensi Dasar (KD) tuntutan dari Standar Isi dapat disampaikan.

4. Penilaian proses setiap kali kegiatan pembelajaran di kelas, agar dilaksanakan, dengan maksud untuk mengetahui berapa persen ketercapaian KD yang disampaikan.

\section{DAFTAR PUSTAKA}

Bungin, B. 2010. Penelitian Kualitatif. Jakarta: Kencana.

Hubermen, M. A. \& Miles, B. M. 1992. Analisis Data Kualitatif. Universitas Indonesia: UI Press.

Hamidi. 2008. Penelitian Kualitatif, Pendekatan Praktis Penulisan Proposal dan Laporan Penelitian. Malang: Universitas Muhammadiyah Malang.

Mulyasa. 2009. Menjadi Kepala Sekolah Profesional. Bandung: PT Remaja Rosdakarya.

Peraturan Menteri Pendidikan Nasional Republik Indonesia Nomor 162/U/2003 tentang Pedoman Penugasan Guru Sebagai Kepala Sekolah.

Peraturan Menteri Pendidikan Nasional Nomor 13 Tahun 2007 Tentang Standar Kepala Sekolah.

Sahertian, P. 2008. Konsep Dasar dan Teknik Supervisi Pendidikan dalam Rangka Pengembangan Sumber Daya Manusia. Jakarta: PT Rineka Cipta.

Sukari. 1999. Studi Korelasional Antara Persepsi Widyaiswara Terhadap Jabatannya dan Motivasi Berprestasi dengan Kinerja Widyaiswara. Jurnal Teknologi Pendidikan Nomor 1, Desember 1999 (P:50;52) 
Sugiyono. 2008. Memahami Penelitian Kualitatif. Bandung: CV Alfabeta Usman, U. 2002 Menjadi Guru Profesional. Bandung: PT Remaja Rosdakarya.

Undang Undang RI Nomor 20 Tahun 2003, Tentang Sistem Pendidikan Nasional. Jakarta: Direktorat Jenderal Pendidikan Dasar dan Menengah Bagian Proyek Penilaian Hasil Belajar Tahap Akhir Nasional. 